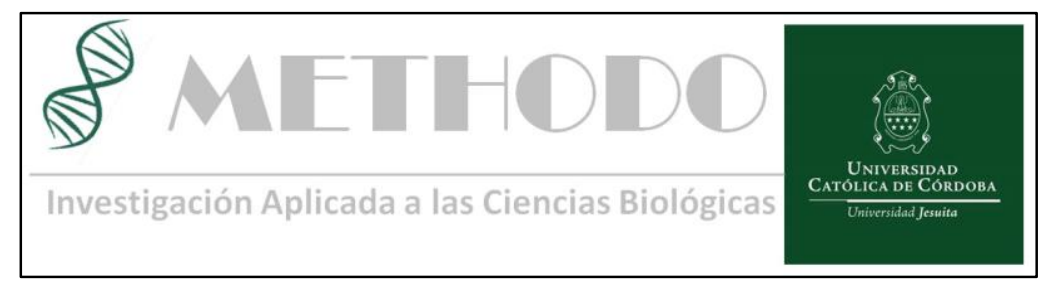

\title{
Esclerosis temporo mesial, evaluación diagnóstica y resultados.
}

\section{Temporus mesial Sclerosis, diagnostic evaluation and results.}

\author{
María P. Vaudagna ${ }^{1-2}$, Glenda Vergara ${ }^{1-2}$, Francisco Pueyrredón ${ }^{2-4-5}$, Adrián Muñoz ${ }^{4}$, Ariel Martínez ${ }^{1-2}$, \\ IgnacioSfaello $^{1-2}$, Zenon Sfaello ${ }^{1}$, Sebastián Bulacio ${ }^{3}$. \\ ${ }^{1}$ Servicio de Neurología Infantil, Instituto de Neurología Infanto Juvenil, CETES. Córdoba ${ }^{2}$ Servicio de Neurología Infantil Clínica \\ Universitaria Reina Fabiola. Córdoba ${ }^{3}$ Jefe de Servicio de Diagnóstico por imágenes, Instituto Conci Carpinella, Córdoba. ${ }^{4}$ Servicio \\ Neurocirugía, Hospital de Niños Santísima Trinidad, Córdoba. ${ }^{5}$ Servicio de Neurocirugía, Sanatorio Allende, Córdoba. \\ Correspondencia:
}

\section{Introducción}

La esclerosis temporo-mesial (ETM), dentro de las epilepsias del lóbulo temporal, es el tipo de epilepsia sintomática focal más frecuente, especialmente en formas parciales resistentes a los medicamentos, siendo la cirugía un tratamiento efectivo para la misma con resolución completa entre un 60 a $90 \%^{1}$

$\mathrm{Su}$ fisiopatogenia es debido a la pérdida neuronal segmental y gliosis en el hipocampo; algunos estudios postmortem indican que estos hallazgos también están presentes en una proporción de pacientes en la amígdala, corteza entorrinal y corteza temporal ${ }^{2}$.

Se ha demostrado un aumento de la patología en pacientes que presentaron antecedentes de convulsiones febriles en edad pediátrica, predominando en niños con crisis atípicas, hipoxia perinatal o infecciones en del sistema nervioso central ${ }^{3}$.

La resonancia Magnética (RM) es un método básico y uno de los más versátiles en imágenes de epilepsia. Se ha puesto en evidencia que la sensibilidad de la misma para identificar focos epileptógenos en pacientes refractarios a fármacos antiepilépticos, con sospecha de epilepsia estructural en más del $80 \%$ con un alto rendimiento diagnóstico en pacientes en sospecha diagnóstica de ETM al identificar los cambios según, los ya establecidos, criterios primarios y secundarios para realizar el diagnóstico (Tabla 1). Algunas publicaciones, indican la relación de la atrofia del hipocampo con la pérdida de células neuronales y la intensidad de la señal T2 con el recuento de células gliales, respectivamente ${ }^{4}$.

A pesar de ello, otros métodos diagnósticos muy usados actualmente como la tomografía por emisión de positrones (PET) realizada en el periodo interictal que puede revelar una región hipometabólica focal concordante con el inicio de las convulsiones o la tomografía computarizada por emisión de fotón único (SPECT) que puede ayudar en el período ictal, con dificultad en nuestro medio para lograr realizarla de manera estandarizada, ésta demuestra un aumento en la captación del marcador en la región temporal medial, el cerebelo, el tálamo, la ínsula y el putamen, esto sugiere que en la ETM se asocia a un cambio específico del estado en las redes metabólicas ${ }^{5}$.

Por lo anteriormente dicho la neuroimagen proporciona la posibilidad de mapear estos cambios citoarquitectónicos en pacientes con antecedentes de epilepsia focal, de difícil manejo con fármacos antiepilépticos $\mathrm{y}$, por lo tanto, probables candidatos para tratamiento quirúrgico. El objetivo primario de nuestro estudio es revisar la evidencia del método diagnóstico de la RM en pacientes con ETM operados, comparando con la anatomía patológica posterior.

El objetivo secundario es establecer si existe una relación entre el tiempo de epilepsia previo a la cirugía y su pronóstico posterior. 
Tabla. n $n^{0}$. Criterios Diagnósticos para Esclerosis Temporo-Mesial en Resonancia Magnética

Criterios Primarios

\begin{tabular}{l} 
1. Atrofia y disminución de señal en T1 \\
2. Aumento de señal en hipocampo en T2 y FLAIR \\
3. Perdida de la arquitectura interna en I/R \\
Criterios Secundarios \\
\hline 1. Dilatación del asta Temporal Bilateral \\
2. Atrofia del fónnix y cuerpo mamilar ipsilateral \\
3. Atrofia del lóbullo temporal lipsilateral \\
\hline 4. Perdida de la diferenciación de sustancia grisy blanca del lóbulo temporal \\
\hline 5. Atrofia de Tálamoy Núcleo Caudado \\
\hline
\end{tabular}

Objetivo primario, revisar la evidencia del método diagnóstico de la RM en pacientes con ETM operados, comparando con anatomía patológica posterior.

Objetivo Secundario, establecer si existe una relación entre el tiempo de epilepsia previo a la cirugía y ENGEL posterior.

\section{Materiales y Métodos}

Diseño del estudio: Estudio retrospectivoobservacional, multicéntrico, se incluyeron pacientes desde enero del 2007 hasta enero 2017 pertenecientes a instituciones de la provincia de Córdoba, Instituto CETES, Clínica Universitaria Reina Fabiola, Hospital de Niños Santísima Trinidad y Sanatorio Allende.

Se incluyeron los pacientes con diagnóstico de epilepsia refractaria. Para la misma se utilizó la definición de la Liga Internacional Contra la Epilepsia: todo paciente con epilepsia resistente a fármacos en el que no se han controlado las crisis tras el tratamiento adecuado con dos fármacos antiepilépticos tolerados, adecuadamente elegidos y pautados (bien en monoterapia $\mathrm{o}$ en combinación), entendiendo como falta de control crisis a lo largo de un año o las sufra en un tiempo inferior a tres veces el intervalo entre crisis que mostraba antes de iniciar el tratamiento. Asimismo se incluyó a todo paciente menor a 15 años al inicio de la misma y con diagnóstico de ETM, el cual se realizó por RM 1.5T con protocolo de epilepsia, informadas por un mismo neuroadiólogo. Se comparó el informe de la RM prequirúrgica con la anatomía patología postquirúrgica.

Para establecer la relación entre el tiempo de epilepsia y evolución posquirúrgica se reclutaron los pacientes con un mínimo de tiempo de un año posquirúrgico y se clasificó según la escala de ENGEL, la cual evalúa la presencia de crisis convulsivas, la frecuencia y tipo de las mismas. (Tabla ${ }^{\circ} 2$ )

Se excluyeron los pacientes que presentaron distinta patología en lóbulo temporal (malformación de desarrollo cortical, tumores, malformaciones vasculares) o complicaciones intraquirúrgicas.

Análisis Estadístico: Se analizaron las variables cuantitativas con la prueba U de Mann-Whitney, conviniendo significativa a una p menor a 0.05 . Se utilizó de soporte informático software R-Medic de la Universidad Católica de Córdoba ${ }^{6}$.

\begin{tabular}{|l|}
\hline Tabla. $n^{0}$ 2. Escala de ENGEL \\
\hline CLASE I: Libre de crisis incapacitantes (excluido periodo postoperatorio, 1 mes) \\
\hline A. Completamente libre de crisis después de la cirugía \\
\hline B. Sólo crisis parciales simples \\
\hline C. Algunas crisis después de la cirugía pero libre de ellas desde al menos dos años \\
\hline D. Crisis generalizadas sólo con retirada de fármacos anticonvulsivos \\
\hline CLASE Il: Esporádicas crisis incapacitantes \\
\hline A. Inicialmente libre de crisis, posterior esporádicas \\
\hline B. Esporádicas crisis desde la cirugía \\
\hline C. Crisis inicialmente más frecuentes pero en los dos últimos años esporádicas \\
\hline D. Sólo crisis nocturnas \\
\hline CLASE III: Mejoría significativa \\
\hline A. Reducción significativa del número de crisis \\
\hline B. Intervalos prolongados libres de crisis por un tiempo superior a la mitad del periodo \\
de seguimiento pero no superior a dos años \\
\hline CLASE IV: No mejoría significativa \\
\hline A. Reducción significativa de las crisis (entre 50-90\%) \\
\hline B. No cambio apreciable \\
\hline C. Empeoramiento de las crisis \\
\hline
\end{tabular}

\section{Resultados}

El total de la muestra fue de dieciséis pacientes, once masculinos (68\%) y cinco femeninos (32\%), con un rango etario de nueve años hasta cuarenta y siete años, con una media al momento de la intervención de diecisiete años y una media de catorce años, entre el inicio de los síntomas hasta la cirugía, con un rango de tres hasta cuarenta y siete años. Siete $(45 \%)$ tenían antecedentes de convulsiones febriles.

Según su evolución posquirúrgica y la escala de ENGEL diez pacientes presentaron clasificación IA, uno IB, cuatro IIA y uno IIB, siendo la tasa de remisión total un $62 \%$, que corresponde con los pacientes con clasificación IA (Fig. $\mathrm{n}^{\mathrm{o}} 1$ ).

Quince pacientes (94\%) coinciden el informe RM y anatomía patológica, siendo un resultado significativo (p: 0.02), no se logró establecer entre los años de epilepsia y evolución posquirúrgica (p: $0.5)$, al igual que los pacientes con antecedentes de convulsiones febriles y desarrollo posterior de ETM (p: 0.6).

Revista Methodo: Investigación Aplicada a las Ciencias Biológicas. Universidad Católica de Córdoba. Jacinto Ríos 571 Bo Gral. Paz. X5004FXS. Córdoba. Argentina. Tel.: (54) 3514517299 / Correo: methodo@ucc.edu.ar / Web: methodo.ucc.edu.ar | ARTICULO ORIGINAL Methodo 2018;3(4):115-119 


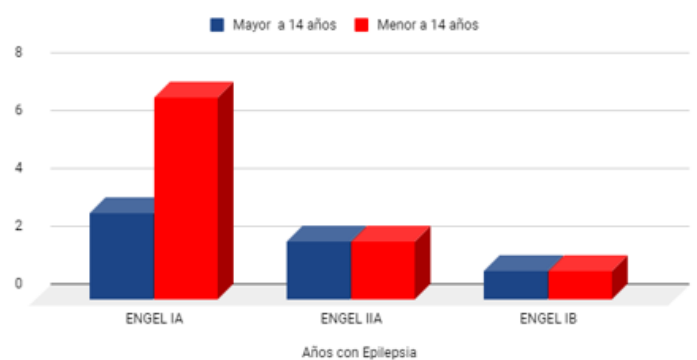

Figura1: Clasificación de ENGEL según el tiempo medio de epilepsia.

\section{Discusión}

Actualmente existen múltiples métodos diagnósticos en pacientes con epilepsia refractaria a la medicación, la importancia radica en la utilización de manera adecuada de los recursos. En el trabajo actual, de la totalidad de los pacientes, el $94 \%$ coincide al comparar el informe de la RM con la anatomía patológica posterior, coincidiendo los resultados con el trabajo de Cendes and cols. ${ }^{4}$ el cual concluye que la solicitud del SPECT puede desempeñar un papel fundamental en la evaluación de pacientes con epilepsia focal resistente a los medicamentos conjuntamente con electroencefalogramas previos para definir el área afectada. Pero al hacer hincapié en la patología tratada en nuestro trabajo, existe un aumento de la sensibilidad para la RM, lo cual hace que se reduzca la solicitud de otros estudios costosos en la evaluación prequirúrgica. Al igual que en el estudio de Adry R A and cols. ${ }^{3}$ donde demuestran una evidencia sólida que los pacientes con diagnóstico de ETM por RM, no hay evidencia de importancia pronostica para realizar SPECT posterior. En dicho estudio también hace referencia a diferentes factores de riesgo que presentan los pacientes con ETM para predecir el pronóstico posquirúrgico. A pesar que en nuestro estudio no se logran resultados significativos según el tiempo de epilepsia, en el mencionado trabajo, con 400 pacientes incluidos, los hallazgos significativos de peor pronóstico a posterior en pacientes sometidos a cirugía son: la extensión de la lesión en RM, antecedentes perinatales patológicos, antecedentes familiares de epilepsia, convulsiones febriles, tipo tónico-clónica generalizadas, la duración y frecuencia de las crisis. $^{3}$

\section{Conclusiones}

La RM de $1.5 \mathrm{~T}$ es un método altamente confiable para diagnosticar ETM, por lo cual ante su sospecha diagnóstica otros estudios serían innecesarios. Sugerimos evaluar otro método diagnóstico cuando la RM no arroje datos suficientes.

En nuestra muestra no se ha podido establecer una relación significativa en cuanto al pronóstico según el tiempo de evolución. Sin embargo, la evidencia en la literatura afirma que a largo plazo son más eficaces las evoluciones postquirúrgicas en los pacientes operados con ETM de reciente diagnóstico. Consideramos necesarios más estudios de mayor casuística y seguimiento a largo plazo para validar estos resultados.

\section{Introduction}

The temporo-mesial sclerosis (MTS), within the epilepsies of the temporal lobe, is the type of focal symptomatic epilepsy more frequent, especially in partial forms resistant to the medicines, being the surgery an effective treatment for the same with complete resolution between 60 to $90 \%{ }^{1}$.

Its pathophysiology is due to segmental neuronal loss and gliosis in the hippocampus; Some postmortem studies indicate that these findings are also present in a proportion of patients in the amygdala, entorhinal cortex and temporal cortex ${ }^{2}$. An increase in the pathology has been demonstrated in patients who had a history of febrile convulsions in the pediatric age, predominantly in children with atypical crises, perinatal hypoxia or infections in the central nervous system. ${ }^{3}$

Magnetic resonance (MR) is a basic method and one of the most versatile in epilepsy images. It has been shown that the sensitivity of the same to identify epileptogenic foci in patients refractory to antiepileptic drugs, with suspected structural epilepsy in more than $80 \%$ with a high diagnostic yield in patients in suspected diagnosis of TMD by identifying changes according to, those already established, primary and secondary criteria to perform the diagnosis (Table 1). Some publications indicate the relationship of hippocampal atrophy with the loss of neuronal cells and the intensity of the T2 signal with the glial cell count, respectively ${ }^{4}$.

In spite of this, other diagnostic methods are widely used today such as positron emission tomography (PET) performed in the interictal period that may reveal a focal hypometabolic region consistent with the onset of seizures or single photon emission computed tomography (SPECT) that can help in the ictal period, with difficulty in our environment to achieve it in a standardized way, this shows an increase in the uptake of the marker in the medial temporal region, the cerebellum, the thalamus, the insula and the putamen, this suggests that MTS is 
associated with a specific change of state in metabolic networks 5 .

Therefore, neuroimaging provides the possibility of mapping these cytoarchitectonic changes in patients with a history of focal epilepsy, difficult to manage with antiepileptic drugs and, therefore, likely candidates for surgical treatment.

The primary objective of our study is to review the evidence of the MRI diagnostic method in patients with TMD operated, comparing with the subsequent pathological anatomy.

The secondary objective is to establish whether there is a relationship between the time of epilepsy prior to surgery and its subsequent prognosis.

Primary objective, to review the evidence of the MRI diagnostic method in patients with MTS operated, comparing with later pathological anatomy.

Secondary Objective, establish if there is a relationship between epilepsy time prior to surgery and subsequent ENGEL.

\section{Material and methods}

Study design: Retrospective-observational, multicenter study, patients from January 2007 to January 2017 belonging to institutions of the province of Córdoba, CETES Institute, Reina Fabiola University Clinic, Santísima Trinidad Children's Hospital and Sanatorium Allende were included.

Patients with a diagnosis of refractory epilepsy were included. The definition of the International League Against Epilepsy was used for the same: all patients with drug-resistant epilepsy in whom seizures have not been controlled after adequate treatment with two tolerated antiepileptic drugs, appropriately chosen and prescribed (either monotherapy or in combination), understanding as a lack of crisis control over a year or suffer in a time less than three times the interval between crises that showed before starting treatment. Likewise, all patients under 15 years of age were included at the beginning of the study and with a diagnosis of MTS, which was performed by MRI $1.5 \mathrm{~T}$ with an epilepsy protocol, informed by the same neuroadiologist. The report of the presurgical MRI was compared with the postoperative pathology anatomy.

To establish the relationship between the time of epilepsy and postoperative evolution, patients were recruited with a minimum of one postoperative year and classified according to the ENGEL scale, which evaluates the presence of seizures, the frequency and type of seizures. (Table No. 2)

We excluded patients who presented different pathology in temporal lobe (malformation of cortical development, tumors, vascular malformations) or intra-surgical complications.

Statistical Analysis: Quantitative variables were analyzed with the Mann-Whitney U test, meaning significant at $\mathrm{p}$ less than 0.05 . R-Medic software from the Universidad Católica de Córdoba was used ${ }^{6}$.

\section{Results}

The total of the sample was of sixteen patients, eleven masculine $(68 \%)$ and five feminine $(32 \%)$, with an age range of nine years up to forty-seven years, with an average at the time of the intervention of seventeen years and an average of fourteen years, between the onset of symptoms until surgery, with a range of three to forty-seven years. Seven $(45 \%)$ had a history of febrile seizures.

According to their postoperative evolution and the ENGEL scale, ten patients presented classification IA, one IB, four IIA and one IIB, with a total remission rate of $62 \%$, which corresponds to patients with classification IA (Fig. 1).

Fifteen patients (94\%) coincided with the MRI report and pathological anatomy, being a significant result (p: 0.02), it was not possible to establish between the years of epilepsy and postoperative evolution (p: 0.5 ), as well as patients with a history of Febrile seizures and subsequent development of ETM (p: 0.6).)

\section{Discussion}

There are currently multiple diagnostic methods in patients with epilepsy refractory to medication, the importance lies in the proper use of resources. In the current work, of the totality of the patients, 94\% agree when comparing the MRI report with the later pathological anatomy, coinciding the results with the work of Cendes and cols. 4 which concludes that the SPECT request can play a fundamental role in the evaluation of patients with focal epilepsy resistant to drugs together with previous electroencephalograms to define the affected area. But by emphasizing the pathology treated in our work, there is an increase in sensitivity for MRI, which reduces the request for other costly studies in the presurgical evaluation. As in the study by Adry R A and cols. 3 where there is solid evidence that patients diagnosed with MTS by MRI, there is no evidence of prognostic importance for subsequent SPECT. In this study, it also refers to different risk factors that patients with MTS present to predict postoperative prognosis. Although our study did not achieve significant results according to the time of epilepsy, in the aforementioned study, with 400

Revista Methodo: Investigación Aplicada a las Ciencias Biológicas. Universidad Católica de Córdoba. 
patients included, the significant findings of worse prognosis in patients undergoing surgery after surgery are: the extension of the lesion in MRI, pathological perinatal history, family history of epilepsy, febrile seizures, generalized tonic-clonic type, duration and frequency of seizures. 3

\section{Conclusions}

The MRI of $1.5 \mathrm{~T}$ is a highly reliable method to diagnose MTS, for which, in case of its diagnostic suspicion, other studies would be unnecessary. We suggest evaluating another diagnostic method when the MRI does not yield sufficient data.

In our sample, it was not possible to establish a significant relationship regarding the prognosis according to the time of evolution. However, the evidence in the literature affirms that in the long term postoperative evolutions are more effective in patients operated with recently diagnosed TMD. We consider that more studies of greater casuistry and long-term follow-up are necessary to validate these results.

\section{Bibliografía}

1. Wieser H G and col; "ILAE Commission Report. Mesial temporal lobe epilepsy with hippocampal sclerosis"; Epilepsies. 2004 Jun; 45(6):695-714; DOI: $10.1111 / \mathrm{j} .0013-$ 9580.2004.09004. $\mathrm{x}$

2. Adler S and cols; "Multimodal computational neocortical anatomy in pediatric hippocampal sclerosis"; Ann Clin Transl Neurol. 2018 Oct; 5(10): 1200-1210; DOI: 10.1002/acn3.634.

3. Adry R A and cools; "Factors predicting the outcome following surgical treatment of mesial temporal epilepsy due to mesial temporal sclerosis"; Acta Neurochir (Wien). 2016 Dec; 158(12):2355-2363. Epub 2016 Oct 21; DOI: 10.1007/s00701-016-2992-0.

4. Cendes F and cools; "Neuroimaging of epilepsy"; Handb Clin Neurol. 2016; 136: 985-1014; DOI: 10.1016/B978-0-444-534866.00051-X.

5. Jones A L and col; "Evidence on Use of Neuroimaging for Surgical Treatment of Temporal Lobe Epilepsy: A Systematic Review"; JAMA Neurol. 2016 Apr; 73(4):464-70.

10.1001/jamaneurol.2015.4996.

6. Mangeaud A, Elías Panigo DH. 2018 RMedic. Un programa de análisis estadísticos sencillo e intuitivo. Revista Methodo 3 (1) 1822.

\author{
Palabras claves \\ CLEROSIS TEMPORO-MESIAL, LÓBULO \\ TEMPORAL, EPILEPSIA OCCIPITAL, \\ EPILEPSIA REFRACTARIAES.
}

\section{Keywords}

TEMPORO-MESIAL SCLEROSIS, TEMPORAL LOBE, OCCIPITAL EPILEPSY, REFRACTORY EPILEPSY.

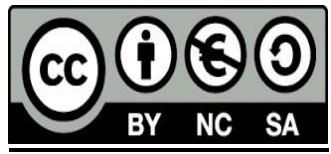

